\title{
MATHEMATICAL IDENTIFICATION OF HOMOGENISATION PROCESSES IN ARGON STIRRED LADLE
}

\author{
Received - Prispjelo: 2008-09-09 \\ Accepted - Prihvaćeno: 2008-12-10 \\ Original Scientific Paper - Izvorni znanstveni rad
}

\begin{abstract}
Mathematical models processed results of experimental investigation obtained during ladle gas argon bubbling realised by stir elements situated in the ladle bottom. Exact theoretical description of processes occurring at argon bubbling into steel would be very complex and it would lead to a system of non-linear partial differential equations describing transfer of momentum, heat, components, and with excitation function in the form of equation of so called deterministic chaos (argon bubbling). On the basis of pouring ladle model diagram and concentrations courses, the simplified linear physically adequate model was proposed, which described behaviour of steel concentration in pouring ladle during its bubbling. The analysed process was understood in the form of a cybernetic model.
\end{abstract}

Key words: steel, ladle, gas argon bubbling, stir elements, physical modelling, mathematical identification

Matematička analiza procesa homogenizacije u loncu s argonskim miješanjem. Matematičkim modelima obrađeni su rezultati eksperimentalnog instraživanja homogenizacije u loncu s argonskim mješačima. Egzaktan teorijski opis procesa uvođenja mjehurića argona u čeličnu talinu bio bi vrlo kompleksan i vodio bi ka sustavu nelinearnih diferencijalnih jednadžbi za opis prijenosa momenta gibanja, topline i elemenata, uz dodatnu funkciju takozvanog determinističkog kaosa (gibanje mjehurića argona). Temeljem dijagramskog modela i koncentracijskih krugova predložen je pojednostavnjen, fizikalno odgovarajući linearni model, koji prikazuje promjenu koncentracije čelične taline u ljevačkom loncu tijekom upuštanja mjehurića. Analizirani process smatran je pritom kibernetičkim modelom.

Ključne riječi: čelik, lonac, upuštanje argonskih mjehurića, mješači, fizikalno modeliranje, matematička identifikacija

\section{INTRODUCTION}

Previously presented paper "Physical Modelling of Bath Homogenisation in Argon Stirred Ladle" was devoted to results of bath behaviour in the ladle model investigation during its gas argon bubbling realised by one or two stir elements situated in the ladle bottom. Study was performed with use of physical modelling method on a scale model 1 to 10 . Development of homogenisation processes after start of bubbling was evaluated on the basis of electrical conductivity and temperature change, which were measured at three points of the ladle volume by conductivity and temperature sensors. The executed works were realised for conditions of 180 tons steel ladles.

It was found that the rate of homogenisation in the steel ladle is significantly dependent on the volume flow of argon. Mathematical method for the identification process was used for determining the optimum flow of argon.

K. Michalek, K. Gryc, Faculty of Metallurgy and Materials Engineering, VŠB-TU Ostrava, Czech Republic

J. Morávka, Material \& Metallurgical Research Ltd., Ostrava, Czech Republic

\section{MATHEMATICAL DESCRIPTION OF PROCESSES AT ARGON BUBBLING}

It was appropriate to create a physical-mathematical (physically adequate) model for the measured time courses of tracing substance concentrations in physical model of pouring ladle (PL) occurred during argon bubbling into the steel.

\section{Description of situation}

Schematic representation of situation at argon bubbling into bath in the model of steel ladle (mLP) is shown in Figure 1.

Argon bubbles flow from eccentrically situated stir element $(\mathrm{P})$ in the bottom of $\mathrm{mLP}$ at constant volumetric flow $(q)$. They ,disrupt" the layer of concentration enriched and coloured water with thickness $\left(h_{\mathrm{k}}\right)$ and there occurs gradual mixing of enriched and clear liquid (steel, water). Two (pressure) forces II and I act basically against each other on molecules of water in proximity of the sensors. 


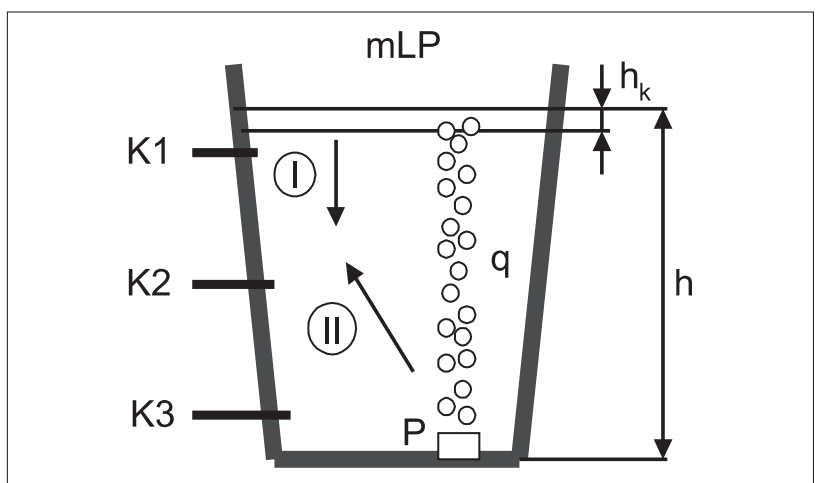

Figure 1. Argon bubbling into ladle model

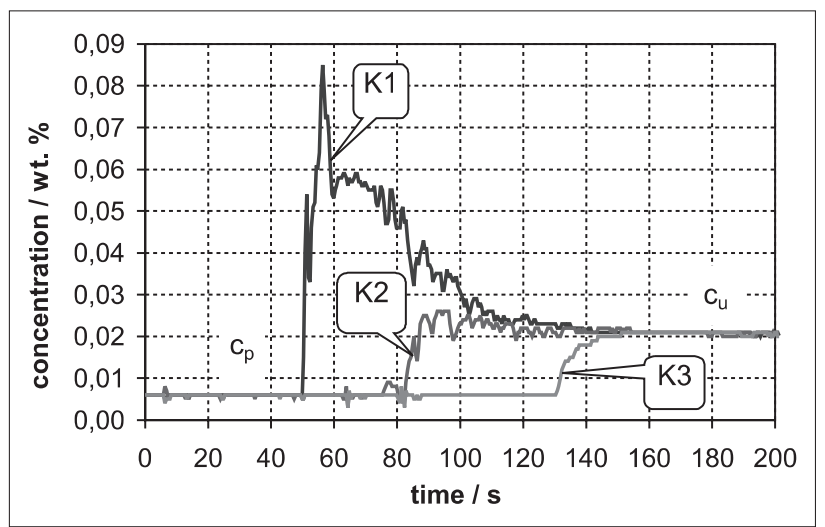

Figure 2. The time response of concentrations on the sensors $\mathrm{K} 1, \mathrm{~K} 2$ and $\mathrm{K} 3$

\section{Measured data}

Analysis and synthesis of mathematical models was realised with use of the data measured on physical model, where courses of the measured concentrations, (with period of sampling $\Delta \tau \approx 0,5 \mathrm{~s}$ ), had on the sensors $\mathrm{K} 1, \mathrm{~K} 2$ and $\mathrm{K} 3$ are shown in Figure 2.

Several facts are obvious from the development of concentration in the sensors:

- start and progress of gas argon bubbling into steel can be approximately considered in the form of the Heaviside unit step function and it is therefore possible to consider the development of concentration as a unit step response,

- the sensors reacted only after elapsing of certain "dead time", which is proportional to the distance of individual sensors from the liquid level in the mLP,

- the overshoot of courses (apparently proportional to the magnitude of the force I or rather to the difference of the forces I and II) also descends with the distance from the liquid level in the mLP,

- steady-state (final) value of concentration is proportional to the proportion of volumes of pure water and water with enriched concentration.

\section{Physical-mathematical model}

Exact theoretical description of processes occurring at argon bubbling into steel would be very complex and it would lead to a system of non-linear partial differen-

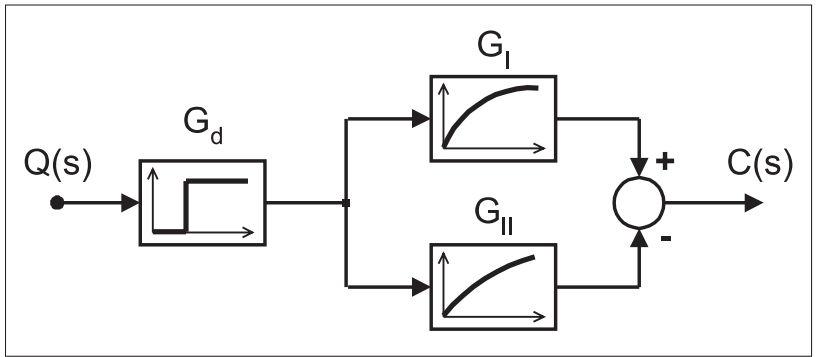

Figure 3. Block diagram of processes in ladle model $(\mathrm{mLP})$

tial equations describing transfer of momentum, heat, components, and with excitation function in the form of equation of so called deterministic chaos (argon bubbling). On the basis of the mLP diagram and concentrations courses, the simplified linear physically adequate model was proposed, which described behaviour of steel elements concentration in PL during its bubbling. Analysed process was understood in the form of a cybernetic model, which can be transparently visualised by so called block diagram shown in Figure 3.

It is series-parallel connection of three components, namely component of time delay and two parallel proportional (inertial) components acting against each other.

Two parallel and antagonistically connected simplest proportional systems with inertia of the $1^{\text {st }}$ order (with transfers $\mathrm{G}_{\mathrm{I}}$ a $\mathrm{G}_{\mathrm{II}}$ ) are assumed for the part of the model without time delay [1]:

$G_{I}(s)=\frac{k_{1}}{\tau_{1} s+1}, G_{I I}(s)=\frac{k_{2}}{\tau_{2} s+1}$

where:

$k_{1}, k_{2}-$ coefficients of transfer (amplification) of systems $/ \% \times \mathrm{s} / \mathrm{m}^{3}$,

$\tau_{1}, \tau_{2}$ - time constants of systems / $\mathrm{s}$,

$s \quad$ - complex variable in the Laplace transform $/ \mathrm{s}^{-1}$.

For this part of the model it is then possible to compose on the algebra basis of transfer the following continuous L-transfers (for zero initial conditions):

$$
\begin{aligned}
G(s) & =\frac{k_{1}}{\tau_{1} s+1}-\frac{k_{2}}{\tau_{2} s+1}= \\
& =\frac{\left(k_{1}-k_{2}\right)+\left(k_{1} \tau_{2}-k_{2} \tau_{1}\right) s}{\left(\tau_{1} s+1\right)\left(\tau_{2} s+1\right)}
\end{aligned}
$$

Wherefrom for the L-image and original of transfer function $H(s)$ and $h(\mathrm{t})$ we get the final expression for standard concentration transfer function, which can be used at the same time as non-linear regression model F1 with three parameters $k_{1}, \tau_{1}$ and $\tau_{2}$ :

$$
h(t)=c_{n}(t)=1-k_{1} \cdot \exp \left(-t / \tau_{1}\right)+\left(k_{1}-1\right) \cdot \exp \left(-t / \tau_{2}\right)
$$

\section{Regression model for all concentrations}

Figure 4 shows courses of the regression function based on the model F1, for standard concentration values in all three sensors K1, K2 and K3. 


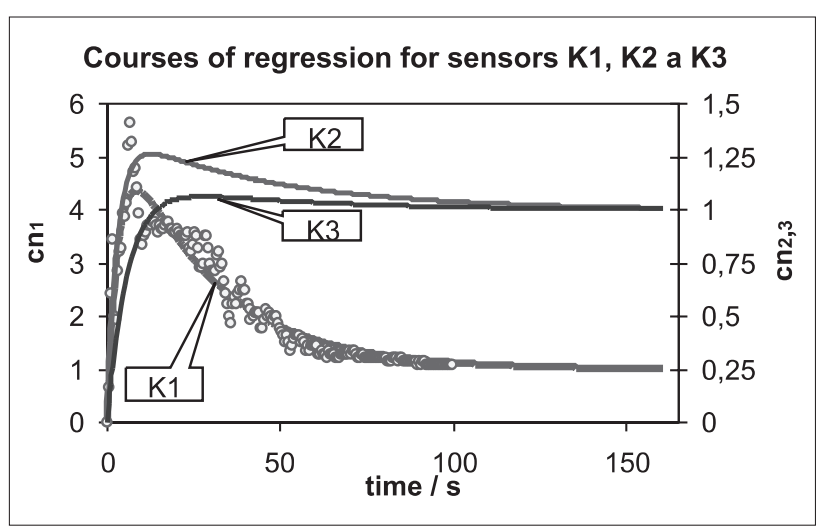

Figure 4. Courses of regression of F1 model for data

It is obvious from the results that the model F1 is suitable and usable for description of concentration course for all three sensors. It is also obvious that the transfer coefficient (gain coefficient) $k_{1}$ decreases with the distance of the sensor from the liquid level in the $\mathrm{mLP}$, while the time constant $\tau_{2}$ increases in this dependence.

\section{USE OF MODEL FOR EVALUATION OF EXPERIMENTS}

Proposed physically adequate model F1 was used for evaluation of the physical modelling results at argon bubbling in the ladle model. Its parameters were used for determination of other aggregated parameters, and all of them where used for definition of an optimum range of blown argon flow. The paper documents results of one stir element for position ,A“ in the ladle bottom.

\section{Approaches to solution}

Three groups of parameters were chosen for characterisation of homogeneity,,intensity“ measure in respect to blown argon flow $q$ : basic physical parameters of model (2 parameters - see the model in Figure 3 and time delay, i.e. $k_{1}, k_{2}$, and $\tau_{\mathrm{d}}$ ), aggregated parameter defining derivative time constant ( 1 parameter, i.e. $\tau_{\mathrm{D}}$ ), and aggregated parameters defining maximum of model transfer function ( 2 parameters, i.e. $t_{\mathrm{m}}$, respectively $\mathrm{t}_{\max }$, and $h_{\mathrm{m}}$ ). Aggregated parameters were chosen in order to achieve simplicity, clarity and appropriate interpretability of homogenisation process.

\section{Parameters of physically adequate model}

Graphical dependencies of foregoing mathematical model parameters on blown argon flow for the sensor $\mathrm{K} 2$ are shown in Figure 5:

It is obvious from the Figure 5 that physically adequate model, in conformity with the assumed behaviour of real system, has evaluated a trend of dependence of the transport delay $\tau_{\mathrm{d}}$ on the argon flow rate. At higher flow rate homogenisation starts sooner and runs more rapidly.

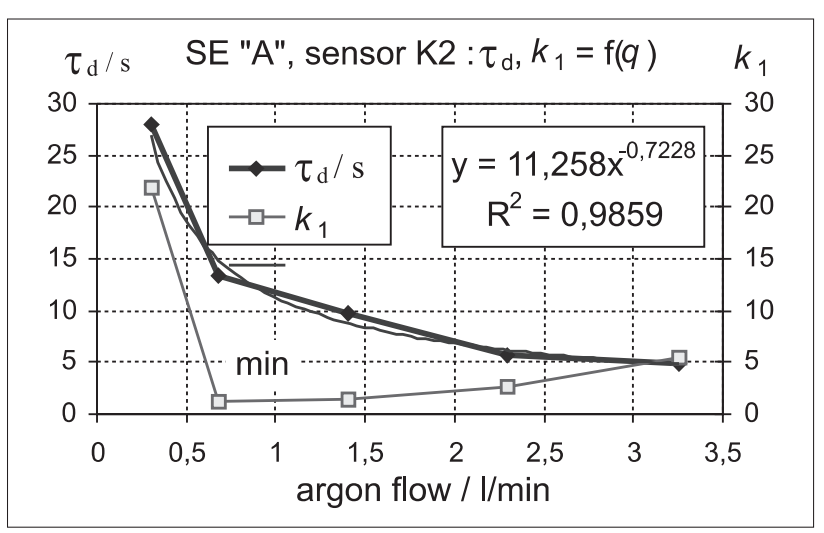

Figure 5. Dependencies of parameters $\tau_{\mathrm{d}}, k_{1}$ on argon flow for the sensor K2

\section{Derivative time constant}

Overall L-transfer of the defined model has character of so called real derivative member with a delay of the $2^{\text {nd }}$ order [2], and derivative time constant $\tau_{\mathrm{D}}$ is function of all three parameters. The constantc $\tau_{\mathrm{D}}$ an be expressed from the equation (2) with use of the relation:

$$
\tau_{D}=k_{1}\left(\tau_{2}-\tau_{1}\right)+\tau_{1}
$$

Lower values of this derivative time constant $\tau_{\mathrm{D}}$ express faster reaction of the model on change of the input value, which is in this case represented by the volume flow of argon.

Graphical dependence of this time constant on the argon flow (for measurement at the sensor K2) is shown in Figure 6.

It is obvious from the Figure 6 that increase of the volume flow of argon to $1,4 \mathrm{l} / \mathrm{min}$ causes a significant step change of the value $\tau_{\mathrm{D}}$ and therefore also more rapid changes in chemical composition of the model liquid (and development of homogenisation). The value of $\tau_{\mathrm{D}}$ does not change significantly with further increase of the argon flow rate.

\section{Transfer function overshoot}

This approach uses analytical relations for determination of transfer function position and transfer function maximum values. Graphical dependencies of the as-

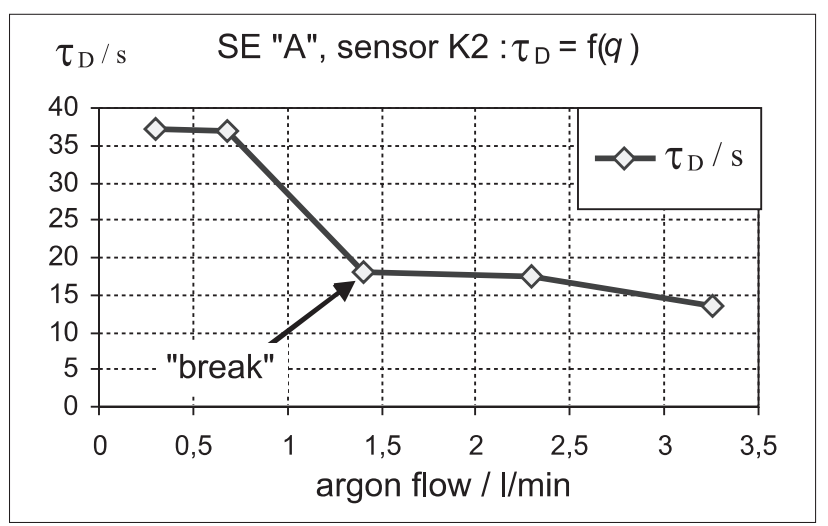

Figure 6. Dependence of derivative time constant $\tau_{\mathrm{D}}$ on argon flow for the sensor K2 


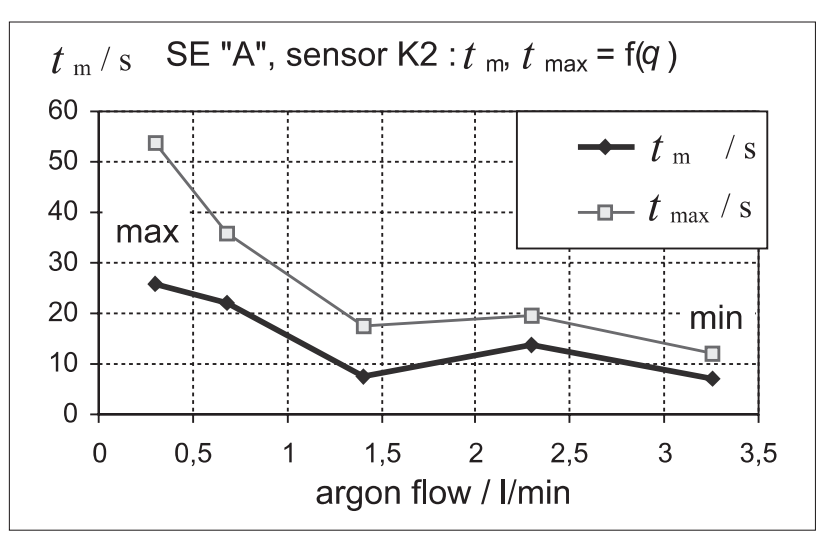

Figure 7. Dependencies of maximum times $\left(t_{\mathrm{m}}, t_{\mathrm{max}}\right)$ of the flow of inert gas for the sensor K2

sumed aggregated maximum parameters of the blown argon flow for the measurement at sensor $\mathrm{K} 2$ are shown in Figure 7 and Figure 8.

Diagram in Figure 7 shows development of times for achieving of maximum values in the impulse function in dependence on the argon flow rate $\left(t_{\mathrm{mx}}\right.$ on the axis $y$ is a general expression of time parameters $t_{\mathrm{m}}$, which is a time of achieving the maximum regardless of transport delay $\tau_{\mathrm{d}}$, or $\tau_{\max }$ ). It is possible to obtain values of the parameter $t_{\max }$ by adding the parameter $\tau_{\mathrm{m}}$ to the transport delay $\tau_{\mathrm{d}}$. Gradual convergence of $t_{\mathrm{m}}$ and $t_{\max }$ is given by decrease of the transport delay $\tau_{\mathrm{d}}$ with increasing volume flow of argon. Faster circulation of volume of liquid results in faster achieving the maximum values of the impulse function. This speed, however, steeply falls at argon flow rates below $1,4 \mathrm{l} / \mathrm{min}$.

The Figure 8 is devoted to a description of dependence of the maximum value of the impulse function $\left(h_{\mathrm{m}}-\right.$ maximum value of dimensionless concentration) on the volume flow of argon. At its lowest flow rate $(0,31 / \mathrm{min})$ the injected substance gets to the sensor K2 in concentrated condition without being mixed. At increase of the argon flow rate to $0,68 \mathrm{l} / \mathrm{min}$ the faster dispersion of the marking substance at the expense of the speed of circulation of the volume of model liquid manifests itself the most from the viewpoint of this parameter $\left(h_{\mathrm{m}}\right)$. Further increase in argon flow rate brings about again a gradual enforcing of speed of circulation. At the highest argon flow rate $(3,25 \mathrm{l} / \mathrm{min})$ the rate of circulation is too high and injected substance gets to the sensor K2 without being able to disperse in the volume of the liquid.

\section{CONCLUSION}

Physically adequate mathematical model was proposed and verified for the measured time response of substance concentrations in the pouring ladle model bath.

This model was used for subsequent analysis of the input simulation parameters influence on its coefficients and aggregated parameters with consequences on appropriate (optimum) working mode setting for steel bubbling in the pouring ladle. Due to pre-set various

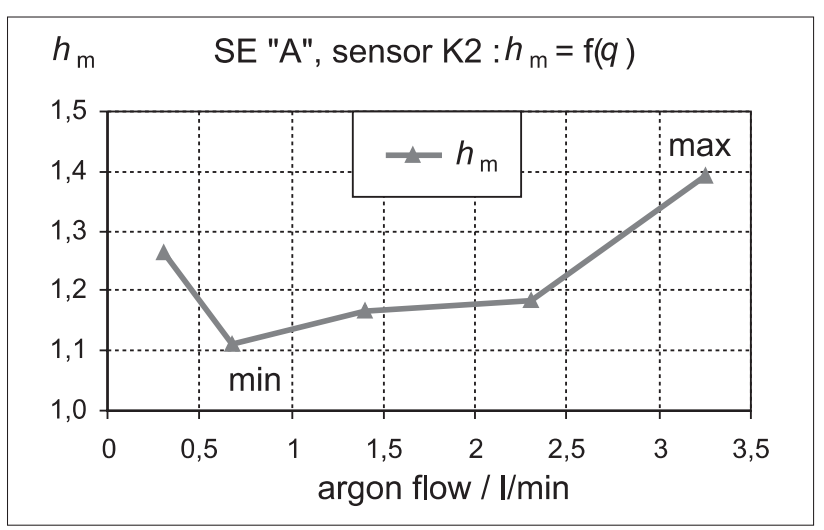

Figure 8. Dependencies of maximum values $\left(h_{\mathrm{m}}\right)$ on the flow of inert gas for the sensor K2

flows of argon blown into bath three groups of (aggregated) parameters for homogenisation intensity characterisation were determined and verified.

On the basis of the shape of their course, the argon flow optimum range was deduced - within limits from approx. 1,4-2,3 1/min (on the ladle model), which can be transformed with use of the appropriate volumetric flow scale factor to the realistic industrial equipment conditions, i.e. 243 - 400 1/min.

It was established in the previous paper entitled „Physical Modelling of Bath Homogenisation in Argon Stirred Ladle" that after achievement of a certain „breakpoint" volume flow its further increase brings low efficiency from the viewpoint of homogenisation times. Parameters assumed in this work enable moreover a more detailed investigation of the character of homogenisation process, correct setting of which forms an integral part of the advanced secondary metallurgy [3, 4]. For example magnitude of the maximum values of the impulse function $\left(h_{\mathrm{m}}\right)$ at individual argon flow rates gives evidence about behaviour e.g. of alloying additions injected into the volume of real pouring ladle at the initial stage of homogenisation.

The work was realised within the frame of solution of the grant project No.106/07/0407 under financial support of the Czech Science Foundation.

\section{REFERENCES}

[1] A. Víteček, L. Smutný, J. Kusyn, Teorie řízení I. Základní pojmy a řešené př́iklady z Laplaceovy transformace. III. [Management theory I. Basic notions and solved examples from Laplace's transformation. III.], VŠB-TU Ostrava, Ostrava, 1988.

[2] S. Kubík, et al., Teorie regulace - I. Lineární regulace [Theory of regulation - I. Linear regulation]. SNTL, Praha, 1974.

[3] J. Krajcar, Metalurgija 32 (1993) 3, 87-92.

[4] V. Ferketić, J. Krajcar, A. Ivančan, Metalurgija 35 (1996) 1, 43-48.

Note: The responsible translator for English language is B. Škandera, Czech Republic. 